\title{
Fiinancial Stability and Reform of the Financial System
}

Juraj Sipko

\section{Abstract}

The paper describes the main features of financial stability and the preparation of the reform of the global financial system. The mortgage crisis in the USA brought about the global financial crisis. This crisis was the result of the failure of financial regulation, including supervision, and the failure of the management of the banking industry. Therefore, the international community, including Group 20, urged the appropriate institutions to introduce a comprehensive reform of the financial sector.

To avoid a potential financial crisis, the creation of the framework for financial stability would be needed. In line with this, the paper examines the interaction between both monetary and fiscal policies, including micro-and macroprudential policies and their instruments. Although still is going on discussion on definition of macroprudential policy, there is a generally accepted opinion that macroprudential policy should limit systemic risk. In addition, this policy should focus on interaction between the financial system and the real economy. Furthermore, micro- and macroprudential policy should use appropriate instruments in dealing with the systemic risk. In this regard, the article undescores that put in a place the framework for financial stability will create favorable conditions for decision-makers how they should to respond to financial imbalances.

The paper also pointed out some potential economic costs related to the implementation of the overall international reform of the financial sector. Based on comprehensive literature study, the author came to the conclusion that despite the fact that there will be some economic costs related to implementing the overall regulatory reform of the financial sector, the main benefit from the long-term perspective will be avoiding the potential financial crisis in the future. To fulfill all the requirements for global financial reform, international cooperation will be needed.

Keywords: | financial stability, macroprudential regulation, financial sector reform

JEL clasificatioin: G15, G18, G35

\section{Introduction}

The mortgage crisis in the USA first caused the global financial crisis. The global financial turmoil split mostly among developed countries. There were some factors 
which significantly contributed to the crisis. Alhough there is no general agreement which factors played a dominant role in the global financial turmoil, it is clear based on „The Financial Inquire? Commission Report ${ }^{1 \text { )“ }}$ that the financial crisis was avoidable.

Many factors contributed to the global financial crisis. In particular, the failure in financial regulation and supervision, failure of rating and audit companies, failure of corporate governance and risk management, a combination of excessive borrowing and lack of transparency, irresponsible action of the government, lack of accountability and ethics, deregulation of the financial sector, expansionary monetary policy, including the global imbalances, etc. The combination of all these factors brought about the mortgage crisis, which was the trigger for the global financial crisis. In order to avoid a future financial crisis, creating an institutional and legal framework, is essential. Therefore, the implementation of macroprudential policy would be needed.

\section{Literature}

Historically, in defining financial stability, two group of researchers appeared. The first group was concentrated on analyzing the external financial shocks and theit impact on the financial stability (Allen and Wood, 2006). The second approach in defining the financial stability was oriented on resilence to shocks which were caused by the financial system (Schinashi, 2004). This idea was later developd by (Borio and Drehman, 2009) emphasising the vulnerability to financial distress is in response to mainly normal shocks.

Macroprudential policy has specific tools. These tools are oriented to limit the risks and costs of systemic crises. In line with the systemic risk, Brunnermeir (2009) emphasized that the purpose of macro-regulation is to act as a countervailing in measuring the risks.

A key element of the discussion of macroprudential policy is the interaction between both the financial instability and the macroeconomy. In this context (Borio and Drehmann, 2009) clearly defined the macroeconomic costs. The analysis of differences between macro- and microprudential policy is further pointed out Borio (2001). Some authors, (Perotti and Sanchez, 2009), as part of macropredential policy, include negative externalities which might have caused the systemic risk on the financial sector. In addition, underscored the significance of macroprudential policy in terms of social costs of reducing the assets in the financial sector. For adopting the financial stability framework, macroprudential instruments will play a critical role.

\section{Macroprudential policy}

The main aim of macroeconomic policy, in particular monetary policy, is price stability ${ }^{2)}$. In line with the outbreak of the global financial crisis, the main question raised was whether the monetary authorities should take into consideration only the price level development or also the development of some main indicators in the financial sector. Therefore, in this regard, has been adopted a new macroeconomic policy e.g.,

1) In the conclusion of the "Financial Commission Inquire Report" was noted that "The crisis was a result of human action and inaction, not of Mother Nature or computer models gone hayware".

2) The European Central Bank consider the main objectives the price stability, which is defined by the consumer price index and core inflation. However, some other monetary outhorities, including the Feredal Reserve System (FED) has defined as main goals their monetary policy not only thier price stability, but also support of economic growth and increasing employment. 
macroprudential policy framework. This comprehensive policy focuses on financial stability ${ }^{3)}$. The key element of macroprudential policy are macroprudential tools.

\section{Macroprudential Tools}

Although still there is ongoing discussion in the literature on monetary policy, there is a clear agreement on macroprudential instruments and their role in macroprudential policy. A majority of authors pointed out that the key macroeconomic instrument, mainly in monetary policy, is the interest rate ${ }^{4)}$ (Blinder, 2008). Since the interest rate is used for achieving price stability, Tinberger (1952) pointed out that in practice, at least one other instrument should be for monetary policy. In line with global financial turmoil, Schoenmaker and Wierst (2011) noted that instead of using the interest rate as the primary instrument for moneraty policy, some additional instruments for macroprudential and microprudential policies are needed.

Despite the fact that expansionary monetary policy was less efficient ${ }^{5)}$ after the break up of the global financial crisis than it was expected, the world leading central banks adopted the so called non-conventional instruments of monetary policy. In the latest research papers, Curdia and Woodford (2009), Christiano et al. (2010) and Lenza et al. (2010) noted that policy rate in extreme situations might be at a very low rate.

Despite the fact that research, academia and policymakers have been extensively discussing the issue in various forms, there is still a lack of comprehensive macroprudential literature. Even though there is ongoing investigation of the main macroprudential instruments, so far it has not been identified in real life ${ }^{6)}$. Some authors, mainly from IMF staff (Caruna, 2010) developed the distinction in defining the macroprudential instruments in terms of mitigating systemic risk. In this regard, they set up two conditions. First, the instrument should be focused on systemic risk and second, in line with this, institutional framework should be put in place.

Implementation of macroprudential policy instruments is critical not only in developed, but also in emerging economies. Recently, these countries have faced some currency mismatches, which are stronlgly influenced by the consequent growth of capital inflows. Open foreign exchange positions and constraints on various types of assets are pointed out by Turner (2009). In addition, in line with the unprecendented pace of financial globalization, Borio ans Shim (2007) pointed out the fact that growing financial imbalances are connected with the growing share of net-foreign exchange financing. In this regard, very useful analysis was provided by Korinek (2010). Based on an analytical framework, he pointed out that there is an interaction between financial instability, macroeconomic conditions and capital flows.

3) Despite the fact that discussion on financial stability is in line with the outbreak of the global financial crisis, so far, there generally does not exist an accepted definition on fnancial stability.

4) Historically, (Tinberger, 1952) emphasized that policymakers need at least one independent instrument for each policy objective in his well-known „Tinberger principle“.

5) The main central banks, e.g., European Central Bank, Federal Reserve System, Bank of England, Bank of Japan, Bank of Canada, Bank of Austrailia, Risksbank etc., in order to support economic growth, after the outbreak of the global financial crisis, it is imperative that they promptly and significantly, in a coordinated way, reduce their interest rates. Despite this explanatory coordinated policy, the monetary policy was less effective that was expected.

6) Despite the various approches to macroprudential policy, there has been a clear distinction between macroprudential instruments that support financial stabilty, such as fiscal instruments (Borio, 2009), (Blanchard et al. 2010). 
The present literature has highlighted some very important distinctions in this regard. These distinctions are related to the dimension of financial stability , e.g., procyclicality in the financial system. The researchers, academia and policymakers came to the following distinctions. One important distinction is between tools towards addressing the time dimension of financial stability and how the financial system contributes to systemic risks of individual institutions. In terms of procyclicality, Saurina and Trucharte (2007) and Rupullo et al. (2009) pointed out that the capital requirements are needed. In addition, they underscored that countercyclical requirements should be included. This idea was further developed by Shin (2010) who addressed the statistical provisioning schemes and noted that the existence of some regulatory constraints on bank capital is the best way to convince the markets that trouled banks will be funded. Furthermore, he supported the minimum capital ratios in good times which might have increased the standards that markets could impose in bad times. The interaction between the evaluation of collateral and loan-to-value (LTV) ratios was pointed out in Borio et al. (2001). In addition, he emphasized that loan loss provisions are a very important channel for assessing risk. Furthermore, he underscored that accounting practices, tax constraints and the methodologies used to measure risk cause provisions to increase during business cycle downturns.

\section{Financial stability framework}

The broadly based financial stability framework and macroprudential policy is described in Scheme 1. Before the global financial crisis, there were two main macroeconomic policies - monetary and fiscal ${ }^{7)}$. In line with the appearance of systemic risk, macro- and microprudential policies were introduced. In addition to these policies, it was necessary to establish crisis management. In the ongoing process of financial globalization and the high level of connectedness between domestic and global economies, all these are necessary instruments to deal with the potential domestic and external systemic risks.

\section{Scheme 1. International level of financial sector supervision}

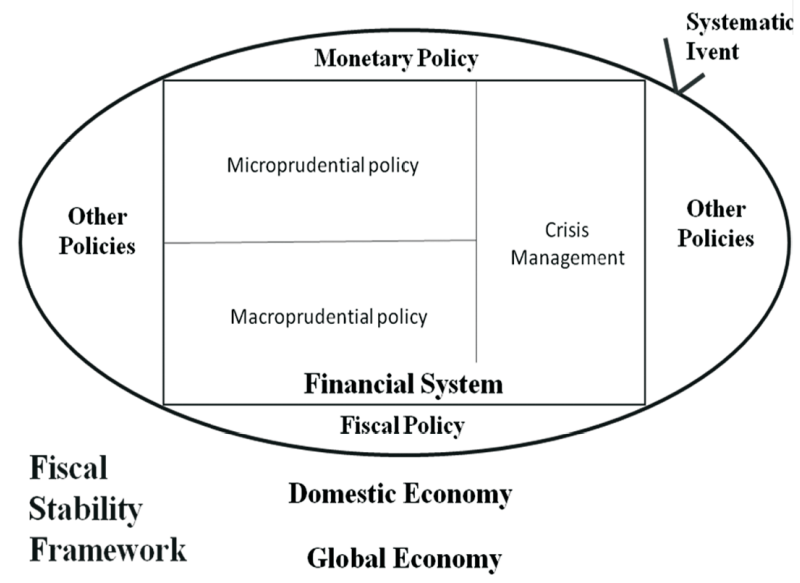

Source: Global Financial Stability, IMF (2010)

7) As part of macroeconomic policy, except monetary a fiscal policies, there is also exchange rate policy not discussed here. 
The global financial crisis has demonstrated the need for a comprehensive reform of the financial system. Therefore, the underlying structure of the international financial and monetary system should be re-evaluated. For the interrelation between macroprudential and microprudential policy, see Table 1 .

Therefore, it was a generally accepted consensus between G208), the International Monetary Fund and Bank for International Settlements to create macroprudential policy ${ }^{9}$. Some factors which significantly contributed to the global financial crisis called the responsible institutions for the creation of a macroprudential framework on regulation and supervision. In order to reach macroprudential goals, appropriate macroprudential tools ${ }^{10)}$ should be established (see Table 2).

\section{Table 1. Macroprudential versus microprudential perspectives}

\begin{tabular}{|c|c|c|}
\hline Policy: & Macroprudential & Microprudential \\
\hline $\begin{array}{l}\text { Proximate objective } \\
\text { Ultimate objective } \\
\text { Characterisation of risk }\end{array}$ & $\begin{array}{l}\text { Limit financial system-wide } \\
\text { distress } \\
\text { Avoid macroeconomic costs } \\
\text { linked to financial instability } \\
\text { "Endogenous" (dependent on } \\
\text { collective behavior) }\end{array}$ & $\begin{array}{l}\text { Limit distress of individual } \\
\text { institutions } \\
\text { Consumer } \\
\text { (investor/depositor) } \\
\text { protection } \\
\text { "Exogenous" (independent of } \\
\text { individual agents") behavior }\end{array}$ \\
\hline $\begin{array}{l}\text { Correlations and common } \\
\text { exposures across institutions }\end{array}$ & Important & Irrelevant \\
\hline $\begin{array}{l}\text { Calibration of prudential } \\
\text { controls }\end{array}$ & $\begin{array}{l}\text { In terms of system-wide risk } \\
\text {-top-down }\end{array}$ & $\begin{array}{l}\text { In terms of risks of individual } \\
\text { insitutions - bottom-up }\end{array}$ \\
\hline
\end{tabular}

Source: Borio (2003)

The lesson we learn from the present financial crisis is that during the boom, companies expand their balance sheets, relying on short-term funding and on increased leverage. In a period when asset prices fall, short-term funding becomes less available, financial institutions are forced to sell assets and deleveraging occurs. Therefore, one very important lesson from the present financial crisis is to increase capital requirements. In line with this, supervisors could increase resilience and reduce leverage.

Table 2. Alternative sets of tools to foster financial stability

\begin{tabular}{|l|l|l|}
\hline \multicolumn{1}{|c|}{ Tool set } & \multicolumn{1}{c|}{ Goal } & \multicolumn{1}{c|}{ Instruments } \\
\hline $\begin{array}{l}\text { Prudential policy: } \\
\text { Microprudential }\end{array}$ & $\begin{array}{l}\text { Limit distress of individual } \\
\text { institutions }\end{array}$ & $\begin{array}{l}\text { e.g. quality/quantity of } \\
\text { capital, leverage ratio }\end{array}$ \\
\hline $\begin{array}{l}\text { Prudential policy: } \\
\text { Macroprudential }\end{array}$ & $\begin{array}{l}\text { Limit financial system-wide } \\
\text { distress }\end{array}$ & $\begin{array}{l}\text { e.g. countercyclical capital } \\
\text { charges }\end{array}$ \\
\hline
\end{tabular}

8) Member countries of the G20 summit in London in April 2009 pledge to: repair the financial system, strengthen regulation to rebuild trust, notably by estalishing a new Financial Stability Board.

9) Macroprudential policy seeks to develop, oversee and deliver an appropriate policy response to the financial system as a whole rather than focusing on individual institutions or certain economic measures in isolation.

10) Introducing macroprudential tools might increase the resilience of the financial system to shocks that originate not only from external sources, but also from the financial markets. 


\begin{tabular}{|l|l|l|}
\hline \multicolumn{1}{|c|}{ Tool set } & \multicolumn{1}{|c|}{ Goal } & \multicolumn{1}{c|}{ Instruments } \\
\cline { 2 - 3 } Monetary policy & Price stability & Policy rate, standard repos \\
\cline { 2 - 3 } Fiscal policy & Liquidity management & $\begin{array}{l}\text { Collateral policies; interest on } \\
\text { reserves; policy corridors }\end{array}$ \\
\cline { 2 - 3 } & $\begin{array}{l}\text { Lean against financial } \\
\text { imbalances }\end{array}$ & $\begin{array}{l}\text { Policy rate; reserve } \\
\text { requirements; mop-up of } \\
\text { liquidity; FX reserve buffers }\end{array}$ \\
\hline \multirow{5}{*}{ Capital controls } & Manage aggregate demand & $\begin{array}{l}\text { Taxes; automatic stabilizers; } \\
\text { discretionary countercyclial } \\
\text { measures }\end{array}$ \\
\cline { 2 - 3 } & $\begin{array}{l}\text { Build fiscal buffers in good } \\
\text { times }\end{array}$ & $\begin{array}{l}\text { e.g. measures to reduce debt } \\
\text { levels; taxes/levies on the } \\
\text { financial system }\end{array}$ \\
\hline \multirow{2}{*}{ Infrastructure policies } & $\begin{array}{l}\text { Limit system-wide currency } \\
\text { mismatches }\end{array}$ & $\begin{array}{l}\text { e.g. limits on open foreign } \\
\text { exchange positions; } \\
\text { constraints on the type of } \\
\text { foreign currency assets }\end{array}$ \\
\hline & $\begin{array}{l}\text { Strenghten the resilience of } \\
\text { the infrastructure of the } \\
\text { financial system }\end{array}$ & $\begin{array}{l}\text { e.g. move derivative trading } \\
\text { on exchanges }\end{array}$ \\
\hline
\end{tabular}

Source: Adapted from Hannoun (2010)

The main goal of macroprudential policy is to enhance the resilience of the financial system and to dampen systemic risks ${ }^{11}$. The financial crisis clearly shows that microprudential regulation was an adequate response to the crisis as a whole. Therefore, microprudential supervision with macrofinancial supervision in dealing with the inter-connectedness of institutions, markets, instruments and accumulative risks should be established.

\section{The Larosière Report}

In February 2009, a Report prepared by the Larosiere group on financial supervision in the European Union was issued. This Report made a series of proposals for establishment of new pan-European supervisory bodies. In March 2009, the European Commission recommended European leaders to endorse the main proposal of the Larosiere Report. In September 2009, the European Commission adopted a set of legislative proposals aimed at strengthening financial sector supervision, which was presented at the G20 summit on the 24th-25th of September in Pittburgh.

The Larosiere Report proposed the establishment of a European System of Financial Supervisors (ESFS). ESFS will be a decentralized network of the three new European financial supervisors charged with carrying out the microprudential supervision of banks, insurance companies and markets. The proposal provides for these authorities to have binding powers as opposed to the three committees they will be replacing, which will play an advisory role (Committee of European Banking Supervisors (CEBS) for

11) Systemic risk has two principal sources. First, there is a strong collective tendency for financial firms as well as companies and households, to overexpose themself to risk in the upswing of a credit cycle and to become overly risk averse in downswing. Second, individual banks typically fail to take account of the spillover effects of their actions on risk in the rest of the financial network. Macroprudential policy would ideally address both sources of systemic risk. 
banks, Committee of European Insurance and Occupational Pensions Supervisors (CEIOPS) for insurance companies and Committee of European Securities Regulators (CESR) for markets). The ESFS will develop and vote by qualified majority on technical standards that will be applied throughout Europe. The standards will only become binding law after formal enforcement by the European Commission. The recent financial crisis revealed deep weakneses in the global financial system. Therefore, this calls for substantial changes to the regultory framework.

\section{International Cooperation}

In order to increase the credibility and consistency of the management of systemic risks creation, an institutional framework for international cooperation is needed. The process of financial globalization in the recent decades demonstrates that systemic risks have developed an increasingly cross-border nature. Therefore, it is almost impossible to control this risk by national authorities. The question is: how to manage the so called side effects of this risk? If the development of integrating financial markets is increasing, then it is called on to create international cooperation. In this regard, the global financial crisis is a wake-up call for the European Commission. For this purpose, a new advisory body European Systemic Risk Board (ESRB) ${ }^{12)}$, was established.

In order to eliminate systemic risk, international cooperation is critical. In this regard, two main bodies for international cooperation, e.g., Financial Stability Board (FSB) and the Intenational Monetary Fund (IMF), have been institutionally established. The latter historically concentrated mainly on macroeconomic issues; in particular, on providing financial facilities in financing external dis-equilibrium current account deficit. However, in line with financial globalization and financial interconnectedness, the G20 decided to delegate the responsilibity to the IMF as a global monetary and financial institution.

\section{Scheme 2: International framework for financial stability}

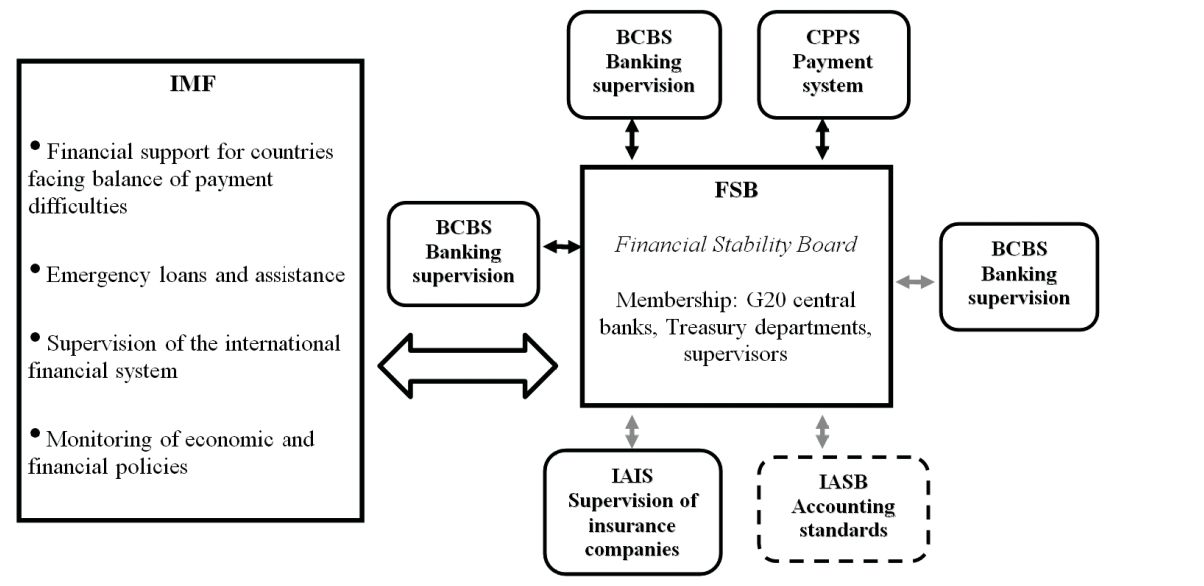

Source: EC, ECB (2009)

12) The European Systemic Board Risk (ESBR), located in the European Central Bank, will conduct macroprudential supervision by assessing the potential threats to financial stability in the European Union. The ESBR will be composed of the ECB General Council members, the future European supervisory authorities, the European Commission and the president of the Economic and Financial Committee. 
The main goal of the IMF in supporting the global financial stability is not only to provide financial needs for current account difficulties and loans and technical assistance for more vulnerable countries, but also to supervise the international financial system, including monitoring of economic and financial policies of its member countries.

The IMF altogether in cooperation with the FSB, which includes G20 and national central banks, ministries of finance and national supervisory authorities ${ }^{13)}$.

\section{Main regulatory reform proposals}

Based on London's G20 declaration, member countries agreed on a set of reforms to strengthen the financial system. Regulatory reforms will focus primarly on improving the resilience of individual institutions and the financial sector. Regarding the banking sector, the Basel Committee on Banking and Supervision (BCBS) provided guidelines and recommendations to improve the resilience of individual banks ${ }^{14}$. The recent proposals of BCBS on capital standards represent a substantial improvement in the quantity and quality of capital in comparison with the price-crisis level (Table 3).

Table 3. BCBS capital and liquidity standards (in percent, all dates are as of 1/1/2011)

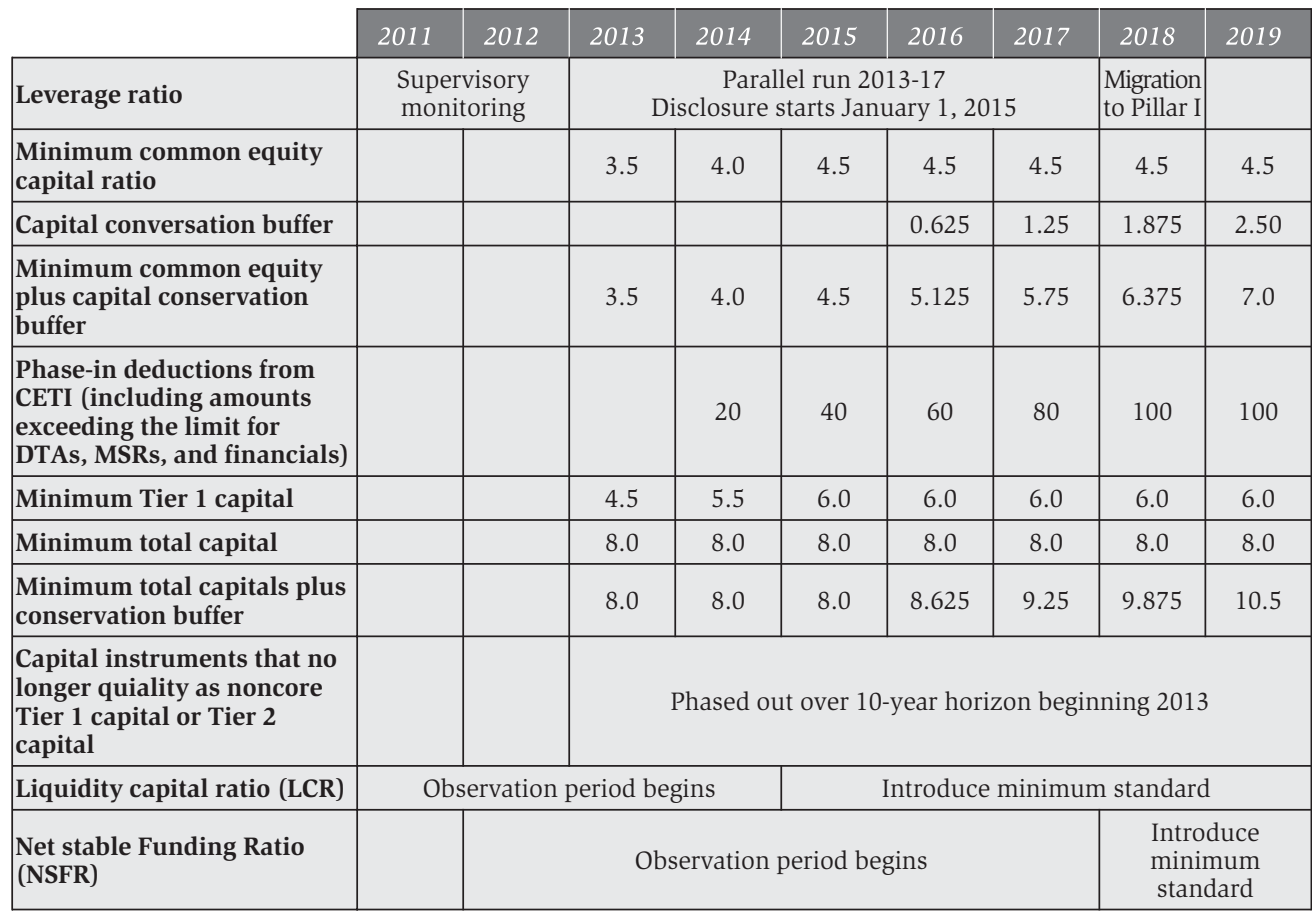

Source: BCBS, Press Release, September 12, 2010

13) The national supervisory authorities will cover the overall financial sector, including the payment system and accounting standards.

14) The crucial components of the BCBS proposals are: higher and better quality capital (mostly common equity, with better loss absorption features), better risk recognition for market and counterparty risks, a non-risk based leverage ratio as a backstop measure, tighter liquidity standards, including a liquid asset buffer for short-term liquidity coverage and a long-term stable funding requirement to limit maturity mismatches and the capital conservation buffer. 
The main improvement of new standards is the following: common equity will represent a higher proportion of capital, in particular, it will increase from 2 percent to 4.5 percent. The amount of intagible and qualified assets will be limited to 15 percent. The implementation period starts in 2013, with gradual introduction of the deductions from 2014 to reach a common equity target of 7 percent by 2019. Banks are expected to comply with revised requirements for trading exposures, counterparty credit risk and exposures to other financial institutions ${ }^{15)}$.

The leverage ratio will be introduced with current regulations on a trial basis, starting with implementation and migration to Pillar 1 by 2018. The Liquidity Coverage Ratio will be implemented in January 2015 after an observation period beginning in 2011. Net Stable Funding Ratio (NSFR) is designed to promote longer-term funding of assets. It will become a minimum standard by January 2018.

\section{Estimated costs}

After more than five years since the global financial crisis started, policymakers and researchers, including international financial institutions, have been able to recognize the costs in terms of economic growth. Therefore, in line with the global financial crisis, G20 and responsible international institutions have been preparing the comprehensive regulatory reform. This reform is considering as the biggest since the Great Depression. Now there is ongoing discussion about the overall costs from the long-term perspective.

In line with the impementation of Basel III, preliminarily identified economic costs have been crucial. Although there are some studies about the overall costs of Basel III implementation, still these are only preliminary. On the global level, there has been some analysis; however, the results are quite different (see Table 4) ${ }^{16}$.

Table 4. Basel III impact on credit and GDP growth

\begin{tabular}{|l|c|c|c|c|c|c|c|c|}
\hline \multicolumn{1}{|c|}{$\begin{array}{c}\text { Basel III } \\
\text { impact }\end{array}$} & \multicolumn{3}{c|}{$\begin{array}{c}\text { Impact on credit } \\
\text { spreads } \\
\text { (bps) }\end{array}$} & \multicolumn{2}{c|}{$\begin{array}{c}\text { Impact on annual GDP } \\
\text { growth } \\
\text { EU }\end{array}$} & \multicolumn{2}{c|}{ Credit GDP } \\
\hline Region & Japan & USA & EU & Japan & USA & Global impact \\
\hline IIF 2012-2019 & 328 & 181 & 243 & $-0,40$ & $-0,30$ & $-0,10$ & 281 & $-0,20$ \\
\hline IIF 2011-2015 & 291 & 202 & 468 & $-0,60$ & $-0,80$ & $-0,60$ & 364 & $-0,70$ \\
\hline OECD 5 years transition & 54 & 35 & 64 & $-0,23$ & $-0,09$ & $-0,12$ & 53 & $-0,16$ \\
\hline BIS long-term capital & 52 & N/A & 52 & $-0,07$ & N/A & $-0,03$ & 52 & $-0,06$ \\
\hline BIS long-term liquidity & 25 & N/A & 25 & $-0,03$ & N/A & $-0,03$ & 25 & $-0,03$ \\
\hline BIS long-term combined & 66 & N/A & 66 & $-0,08$ & N/A & $-0,04$ & 66 & $-0,08$ \\
\hline
\end{tabular}

Source: table set up from data from the IMF

15) See the Basel Committee on Banking and Supervision (July 2009).

16) Table 1, based on the comprehensive analysis of the following institutions: Bank for International Settlements (BIS), International Institute of Finance (IIF) and Organisation for Economic Cooperation and Development (OECD) demonstrates quite different number in terms economic costs for the 3 regions (EU, Japan and USA). 
Therefore, there is some doubt about the economic costs and their impact on economic growth overall. However, to create a safe and efficient financial sector, regulatory reform is essential. There is a generally accepted opinion that there will be some costs in terms of implementing internationally approved regulatory reforms for the financial sector. However, in order to avoid potential financial turmoil, implementation of the overall regulatory reform in the financial sector is a step in the right direction.

\section{Conclusion}

The paper discribes the main features of the micro- and macroprudential policies, financial stability, including the creation of the framework for new global financial reform. The recent global financial crisis raised expectations regarding macroprudential policies. Although there would be overlaps with both microprudential and monetary policy, the role and objectives of macroprudential policy would be distinct.

The main goal of monetary policy is price stability, i.e., to stabilize the aggregate price of goods and services in the economy. Macroprudential objectives are ensuring the resilience of the financial system as a whole. The development of macroprudential instruments is still at an early stage and a consensus on which instruments could be effectively used is under discussion.

The creation of the European Systemic Board Risk as part of the macroprudential policy in the European Union is a step in the right direction. By analyzing the risks arising from both macroeconomic trends and from developments within the financial system, the European Systemic Board Risk will be able to identify both endogenous and exogenous threats to financial stability. Still, there are some open questions regarding the interaction between ESBR and national authorities. There are expectations that ESBR might cooperate effectively with national authorities. Here, again, there are some open questions regarding direct authority and concerning whether implementation relies on cooperation by national supervisors.

The window of opportunity to put in place a fully-fledged macroprudential framework is critical. A macroprudential approach to regulation and supervision is very important to mitigate systemic risk.

The recent Basel Committee on Banking and Supervision proposals on capital requirements represent a substantial improvement in the quality, quantity and comparability of bank capital. The implications of these reforms should be considered as part of the overall package including some other proposals such as countercyclical buffers.

In order to implement the entire global financial regulatory reforms, international cooperation is essential. The key components of the regulatory reforms should be oriented towards mitigation of systemic risk. Therefore, effective use of macroprudential policy instruments requires a greater degree of international cooperation and the establishment of common standards. In line with this set up, an appropriate institutional and legal framework will be needed.

Despite the facts that there will be some additional costs in terms of implementing the internationally accepted financial sector reform, the crucial point here is how big will the potential benefits be in avoiding possible future crises. 
Finally, the banking sector and other financial institutions should continue with the new reform. There is hope that a vigilant implementation of the reforms in the financial sector will have some impact on the economy. However, the economic costs will have limited impact in comparison to long-term benefits in terms of eliminating potential damage from future financial sector crises.

\section{References}

Allen, F. and Babus, A.: Networks in Finance. In. P. Kleidorfer and J. Wind (eds), The Network Challenge, Wharton Shool Publishing, pp. 367-382, (2009).

Allen, F., Babus, A. And Carletti, E.: Financial Connections and Systemic Risk. NBER, Working Papers, No 16177, (2010).

Allen, F., Babus, Wood, G.: Defining Achiving Financial Stability. Journal ofFinancial Stability 2, pp. 152-172, (2006).

Basel Committee on Banking Supervision. „An assessment of the Long-term Economic Impact of Stronger Capital and Liquidity Requirements“. August, (2010).

BIS, Basel Committee on Banking Supervision: Basel III, A Global Regulatory

Framework for Resilient Banks and Banking Systems, December, (2010).

Borio, C.: Towards a macroprudential framework for financial supervision and regulation?

BISWorking Paper No. 128, (2003)

Borio, C and Drehman, M.: Towards an Operational Framework for Financial

Stability: „fuzzy“ Measurement and its Consequences. BIS Working Papers No. 284, (2009a).

Borio, C and Drehman, M.: Assessing the risk of Banking Crisis revisited. BIS, Quarterly Review, March, pp. 29-46, (2009b).

Borio, C. and Shin, I.: What can (Macro)prudential Policy Support Monetary Policy? BIS, Working Paper, No. 242, (2007).

Borio, C., Furfine, C. And Lowe, P.: Procyclically of the Financial System and Financial Stability: Issues of Policy and Options. In Marrying the macro- and Micro-prudential Dimentions of Financial Stability, BIS, Papers, No. 1, pp. 1-57, (2001).

Borio, C. and White.: Whether Monetary Policy and Financial Stability? The Implications of Envolving Policy Regimes, BIS, Working Papers, No. 147, (2004).

Borio, C. And Zhu, H.: Capital Regulation, Risk-taking and Monetary Policy: Missing Linking the Transmission Mechanism? BIS Working Papers, No 268, (2008).

(Blinder, 2008). Borio, C.: Implementing a macroprudential framework: Blending boldness and realism. In: Research Conference „Financial Stability:Towards a Macroprudential Approach", Honk Kong SAR, 5-6 July (2010) available at: http://www.bis.org/reportofficepubl/hkimr201007.12c.pdf

Brunnermeir, M., Crockett, A., Goodhart, C., Persaud, A, and Shin, H.: The Fundamental Pronciples of Financial Regulation. Geneva Reports on the World Economy 11, (2009).

Caballero, R., Krishnamurthy, A.: Global Imbalances and Fnancial Fragility. In: American Economic Review 99, pp. 584-588, (2009).

Caruna, J.: Macrprudential Policy: Working Towards a New Consensus. Remarks at the high level meeting on „The Emerging Frameworkfor financial Regulation and Monetary Policy“. BIS's Fianncial Stability Institute, IMF Institute, Washinghton, D.C., April 23, 2010.

Curdia, V. And Woodford, M.: Conventional and Unconetional Monetary Policy. Federal Reserve Bank of New York, Staff Report, No. 404, (2009).

Christiano, L., Motto, R. And Rostango, M.: Financial Factors in Economic Fluctuations. ECB Working Papers, No. 1192, (2010). 
Financial Stability Board. „Progress since the Pittsburgh Summit in Implementing the G20 Recommendations for Strenghtening Financial Stability“, Report of of the Financial Stability Board to G20 Finance Ministers and Governors, November (2009).

Getler, M. And Karadi, P.: A model of Unconventional Policy. Journal of Monetary Economics, 58 (1), pp. 17-34, (2001).

Hannoun, H.: Towards a global financial stability framework. Speech at the 45th

SEACEN Governors' Conference, Siem Reap Province, Cambodia, 26-27 February 2010.

Hanson, S., Kashyap, A., Stein, J.: A Macroprudential Approach to Financial Regulation. In: Journal of Economics Perspektives. (2010).

IMF, Global Financial Stability Report, (2010).

Korinek, A.: Regulating Capital Flows to Emerging Markets: An Externality View. University Maryland, Mimeo. (2010).

Lenza, M,Pill, H. And Reichlin, L.: Monetary Policy in Exceptional Times. ECB Working Papers, No. 1253, (2010).

Oliveira, A. and Elliott, D.: Estimating the Costs of Financial Regulation, IMF Staff Discussion Note, September 2012

Perotti, E. And Suarez, J.: Liquidity Risk as a Macroprudential Tool. CERP Policy Insight, No. 40, (2009a).

Perotti, E. And Suarez, J.: Liqudity Insurancefor Systemic Crisis. Testimonial at the Select Committee on Economic Affairs for Banking Regulation and Supervision, House Lords. Available at http://www.

Publications.parliament.uk/pa/1d200809/1dselect/1dwconaf/101/9022405.htm

Rupullo, R. and Suarez, J.: The Procyclical Effects of Bank Capital Regulation. European Banking Center Discussion Paper, No.05s, (2010).

Saurina. J and Truchate, C.: An Assessment of Basel II Pocyclicality in Mortgage Portfolios. Journal of Financial Services Research. No. 32. pp. 81-101, (2007).

Schinasi, G.: Safagarding Financial Stability, Theory and Practice. International Monetary Fund, (2004).

Schoenmaker, D and Wierst, P.: Macroprudential Policy: the Need for Coherent Policy Framework. DSF Policy Paper, No 13, (2011).

Shin, H.S.: Financial Intermediation and the Post- crisis Fianncial System. BIS, Working Papers, No. 304. (2010).

Stein, J. C.: Monetary policy as financial- stability regulation. Working Paper, Harvard University (2010) available at: ttp://www.economics.harvard.edu/faculty/stein/files/ MonetaryPolicyAsRegulation-8-2010.pdf

Tiberger, J.: On theory of Economic Policy. Amsterdam, North Publishing Company (1952)

Turner, P.: Currency Mismatches and Loquidity Risk: Diagnosti and Reform. Paper presented at the High Level Workshop on Local Currency Lending and Capital

Market Development in Emerging Europe and Central Asia, London, December 3, 2009.

Ass. professor Juraj, Sipko, PhD.,

Paneuropean University, Faculty Economics and Business,

Tematinska 10

Bratislava,

Slovakia

email: juraj.sipko@uninova.sk 